\title{
OPPRESSION AS A STATUTORY GROUND FOR CORPORATE DISSOLUTION
}

$B_{Y}$ statute in twelve states, ${ }^{1}$ a minority shareholder, alleging oppression by directors or controlling shareholders, may bring an action for dissolution of the corporation. ${ }^{2}$ Although this relief has been available since 1933 in Illinois, ${ }^{3}$ and subsequently has been incorporated in the Model Business Corporation Act $^{4}$ and the other statutes noted, it has received scant judicial attention. Explainable in part, perhaps, by the availability of other more definitive grounds for dissolution in the same statutes, ${ }^{5}$ the disuse of the "oppression" provisions seems to conform to a general pattern of judicial rigidity and disfavor underlying the remedy of involuntary dissolution. ${ }^{8}$ The potential significance of the provision, particularly in the

${ }^{1}$ Ala. Code tit. 10, $\$ 21$ (78) (Supp. 1961); Alaska Stat. \$ 10.05.540 (1962); Itc. REV. Stat. ch. 32, § 157.86 (1953); Iowa Code ANN. § 496A.94 (1962); Mo. ANN. STat. § 351.485 (1952); N.D. CENT. COde § I0-21-16 (1960); ORE. Rev. STAT. § 57.595 (1961); PA. StAT. ANN. tit. 15, $\S 2852-1107$ (1958); Tex. Bus. CoRP. Act art. 7.05 (1956); UTaH Code ANN. § 16-10-92 (Supp. 1963); VA. Code ANN. § 13.1-94 (1956); Wyo. STuT. ANN. § 17-36.86 (Supp. 1963).

2 Almost all states now provide some statutory basis for involuntary dissolution. Most of the statutes which make "oppression" a ground for dissolution have been patterned on the Model Business Corporation Act, which, in turn, was based extensively on the Illinois Business Corporation Act. ABA-ALI MODEL Bus. CoRP. AcT $\$ 90$ (1953) provides in part: "The - courts shall have full power to liquidate the assets and business of a corporation: (a) In an action by a shareholder when it is estab. lished: (1) That the directors are deadlocked in the management of the corporate affairs ... and that irreparable injury to the corporation is being suffered or is threatened by reason thereof; or (2) That the acts of the directors or those in control of the corporation are illegal, oppressive or fraudulent; or (3) That the shareholders are deadlocked in voting power, and have failed, for a period which includes at least two consecutive annual meeting dates, to elect successors to directors whose terms have expired or would have expired upon the election of their successors; or (4) That the corporate assets are being misapplied or wasted." (Emphasis added.)

IL.L. REv. Stat. ch. 32, § 157.86 (1953).

ABA-ALI MODEL BUS. CoRP. Act $\$ 90$ (1953).

- The Model Business Corporation Act includes as alternative grounds for dissolution: director deadlock, illegal or fraudulent acts by directors or controllers, shareholder deadlock, and misapplication or waste of assets. See note 2 supra. For additional grounds provided for under some of the Model Act type statutes, see ALA. Cone tit. 10, $\$ 21$ (78) (a) (4) (Supp. 1961) (cessation of ordinary business); PA. StAT. ANN. tit. I5, $\S 2852-1107$ (A) (1) (1958) (failure or abandonment of corporatc purposes); WYo. STAT. ANN. § 17-36.86 (a) (5) (Supp. 1963) (forfeiture of charter); WYo. STAT. ANN. § 17-36.86 (a) (5) (Supp. 1963) (failure to make annual reports).

- On dissolution at the instance of a shareholder, see generally BaLlantane, Corpora- 
area of the close corporation, seems to warrant an inquiry into the dimensions of "oppression." The purpose of this comment is to ascertain in the decisions, both at common law and under the statutes, the substance of this rather nebulous concept; to indicate factors which weigh upon the appropriateness of dissolution in situations in which oppression has been found; and to suggest the particular utility of the provision in liberalizing the remedy of dissolution.

\section{Common Law Context}

Involuntary dissolution provisions in business corporation acts have been enacted in the face of a traditional judicial reluctance to interfere in corporate affairs. Where nonstatutory relief has been granted to an aggrieved shareholder, it has usually been in the form of an accounting for waste, removal of miscreant directors, or a battery of remedies other than dissolution. ${ }^{7}$ Historically, courts disclaimed even an inherent equitable power to dissolve a solvent corporation, ${ }^{8}$ and many states still cling to this view. ${ }^{9}$ However, in light of a proliferation of exceptions and reversed positions, possession of inherent power to dissolve is now regarded as the general rule.10 Even where common law courts were prepared to dissolve

tions $\$ \S 304-06$ (1946); 2 O’Neal, Czose Corporations: Law and Practice $\$ \S 9.01-29$ (1958); Tingle, The Stockholder's Remedy of Corporate Dissolution (1959).

"See Hornstein, A Remedy for Corporate Abuse-Judicial Power to Wind Up a Corporation at the Suit of a Minority Stockholder, 40 CoLvM. L. REv. 220, 236-38 (1940).

${ }^{y}$ Neall v. Hill, 16 Cal. 146 (1860). Annot., 43 A.L.R. 242 (1926); Annot., 61 A.L.R. 1212 (1929); Annot, 91 A.L.R. 665 (1934).

- E.g., Polikoff v. Dole \& Clark Bldg. Corp., 37 Ill. App. 2d 29, 184 N.E.2d 792 (1962).

20 "There has been a change in rule, and the new rule-that equity has power and will exercise it in appropriate cases-is supported by an overwhelming weight of carefully-reasoned authority." Hornstein, supra note 7, at 220-21.

The lengthy annotations cited supra note 8 set forth numerous cases in which courts have declared that they possessed "no inherent power" to order dissolution of a solvent corporation. Departures from this position, beginning with Miner v. Belle Isle Ice Co., 93 Mich. 97, 53 N.W. 218 (1892), were first regarded as mere aberrations or exceptions to the general rule. Exceptions continued to be made, until, finally, many courts firmly announced their inherent jurisdiction to order dissolution. See TINGLE, op. cit. supra note 5, at 34 n.71.

Professor Hornstein and others suggested that courts frequently have failed to distinguish between power to dissolve in any case and advisability of dissolving in a particular case. Hornstein, supra note $\eta$, at 221.

The question of inherent equitable power has not become necessarily academic by the passage of statutes such as those being considered in this comment. It is not always clear whether the statutory remedy is exclusive. Courts of some states have indicated 
going corporations, however, they invariably labeled the action "drastic."11 Only in the absence of another appropriate remedy would that particular solution be adopted. The decrees were dependent upon a showing of imminent disaster, inevitable ruin, or at a minimum, prospects for serious loss in the near future..$^{12}$

Numerous attempts have been made to catalogue the decisive grounds of the common law decisions. ${ }^{13}$ Fraud, deadlock and misapplication of assets have all been advanced as supporting common law dissolution decrees. ${ }^{14}$ Each of these grounds is incorporated independently in Model Act type statutes. ${ }^{15}$ On the other hand, neither misconduct, gross mismanagement, failure of corporate purposes, abandonment, nor dissension, all of which have justified a shareholder's petition for dissolution under the common law, ${ }^{10}$ is included specifically in the "oppression" statutes. ${ }^{17}$ However, while the transition is somewhat tenuous, the inclusion of the word "oppressive" in the Model Act type statutes may serve the purpose of incorporating these grounds into the dissolution statutes. Without undue violence to its familiar meaning, the single word "oppressive" would seem to cover most of the situations characterized by these classifications of common law decisions.

The fact that "misconduct" and "gross mismanagement" may

that the statute alone establishes a basis for relief. E.g., Polikoff v. Dole \& Clark Bldg. Corp., supra note 9; Milgram v. Jiffy Equip. Co., 362 Mo. 1194, 247 S.W.2d 668 (1952). But in other states, relief may not be limited to statutory grounds. See, e.g., Dorf v. Hill Bus Co., 140 N.J. Eq. 444, 54 A.2d 761 (Ct. Err. \& App. 1947); Guaranty Laundry Co. v. Pulliam, 200 Okla. 185, 191 P.2d 975 (1948).

${ }^{11}$ E.g., First Nat'l Bank v. Fireproof Storage Bldg. Co., 199 Iowa 1285, 202 N.W. 14 (1925).

${ }_{23}$ Dixie Lumber Co. v. Hellams, 202 Ala. 488, 80 So. 872 (1919) (serious loss in the near future and eventual ruin); Benedict v. Columbus Constr. Co., 49 N.J. Eq. 23, 29 Atl. 485 (Ch. 1892) (eventual ruin); Hall v. City Park Brewing Co., 294 Pa. 127, 143 Atl. 582 (1928) (inevitable ruin).

${ }^{13}$ See, e.g., 41 MICH. L. REv. 714 (1943); 28 N.C.L. REv. 313 (1950).

14 Numerous cases indicate that fraud and/or misapplication of assets may justify dissolution. Tower Hill-Connellsville Coke Co. v. Piedmont Coal Co., 64 F.2d 817 (4th Cir. 1933); Henry v. Ide, 208 Ala. 33, 93 So. 860 (1922); Holden v. Lashley-Cox Land Co., 316 Mich. 478, 25 N.W.2d 590 (1947); Miner v. Belle Isle Ice Co., 93 Mich. 97, 53 N.W. 218 (1892); Green v. National Advertising \& Amusement Co., 137 Minn. 65, 162 N.W. 1056 (1917); Goodwin v. Von Cotzhausen, 171 Wis. 351, 177 N.W. 618 (1920). Where shareholders or directors are deadlocked, courts frequently have recognized the appropriateness of dissolution. E.g., Bowen v. Bowen-Romer Flour Mills Corp., 114 Kan. 95, 217 Pac. 301 (1923). Annot., 13 A.L.R.2d 1260, 1264 (1950).

${ }^{25}$ See note 2 supra.

${ }^{10}$ See notes 18-22 infra.

${ }^{17}$ See note 2 supra. But see note 5 supra. 
constitute elements of "oppression" scarcely helps define the term under inquiry, however, since the meanings of these component parts are themselves very broad. But some substance has been injected into these terms by decisions which have held that majority actions such as plundering the corporation, siphoning off profits through excessive salaries to themselves as officers, and running the corporation for the sole benefit of the majority, constitute misconduct or gross mismanagement justifying dissolution. ${ }^{18}$

Failure of corporate purposes, abandonment, and dissension are somewhat more useful concepts in determining what constitutes "oppression" within the meaning of the Model Act statutes. Continuation of the corporate existence after the purposes of incorporation have failed may well be oppressive to one group of shareholders. ${ }^{19}$ There are several holdings to the effect that under such

\footnotetext{
${ }^{18}$ The cases in this area frequently overlap those involving fraud and waste of assets. See note 14 supra. Several cases, however, are demonstrative of situations in which misconduct and mismanagement were emphasized in authorizing dissolution. In Tri-City Elec. Service Co. v. Jarvis, 206 Ind. 5, 185 N.E. 136 (1933), the majority shareholder of a two man corporation misappropriated corporate assets, refused to pay dividends, and excluded the minority shareholder from management. The court approved findings below that the managing shareholder was "not a fit or suitable person to further act in the capacity of managing agent ... of said corporation, and that its business affairs cannot be entrusted to him without involving said corporation in further financial loss." Id. at 15, 185 N.E. at I39. In Klugh v. Coronaca Milling Co., 66 S.C. 100, 44 S.E. 566 (1902), the majority shareholder and principal officer managed a close corporation without consulting the board of directors or minority shareholders, paid himself larger dividends, accepted another job and neglected the corporation, and lost customers for the corporation. Hampton v. Buchanan, 51 Wash. 155, 98 Pac. 374 (1908), involved a majority shareholder and managing officer in a close corporation who raised his own salary to absorb profits and deprived the minority of any voice in management. Accord, Riley v. Callahan Mining Co., 28 Idaho 525, 155 Pac. 665 (1916); Brent v. B. E. Brister Sawmill Co., 103 Miss. 876, 60 So. 1018 (1912); Patton v. Nicholas, 154 Tex. 385, 279 S.W.2d 848 (1955).

A line of Commonwealth cases holds that if misconduct is of a nature and to an extent that it would create a "justifiable lack of confidence," then dissolution will be ordered. E.g., Loch v. John Blackwood, Ltd., [1924] A.C. 783 (P.C.) (B.W.I.).

10 The purposes for which the corporation was chartered may have become illegal. Frequently, with the assets idled, the majority shareholders are in a position to profit at the expense of the minority. Hall v. City Park Brewing Co., 294 Pa. 127, 143 Atr. 582 (1928) (Volstead Act thwarted brewing company purposes). But see Benedict v. Columbus Constr. Co., 49 N.J. Eq. 23, 23 Atl. 485 (Ch. 1891), where it was unsettled whether the law had made the corporate purpose illegal. Changed conditions may have made corporate purposes undesirable if not absolutely unattainable. O'Connor v. Knoxville Hotel Co., 93 Tenn. 708, 28 S.W. 308 (1894) (business and population exodus frustrated corporation organized to build hotel). Some courts have suggested that, in a broader sense, the corporate purpose is to make a profit, and that impossibility of future profitable operations might contribute to a justification for dissolution. Kroger v. Jaburg, 291 App. Div. 641, 248 N.X. Supp. 987 (1981) (business obsolete and
} 
circumstances the majority has a duty to seek voluntary dissolution..$^{20}$ Similarly, where the majority had abandoned the active pursuit of corporate ends, usually with attendant waste of assets and disproportionate personal benefit to the majority, courts have granted a petition for dissolution. ${ }^{21}$ Dissension, to the extent that the conduct of corporate affairs has become ruinously encumbered and ineffective, has also figured prominently in the decisions. ${ }^{22}$

Common law courts, in ordering dissolution, have often spoken of the "fiduciary duty" owed by the majority shareholders to the minority. ${ }^{23}$ This "fiduciary relationship" may also be an important

majority shareholders refrained from dissolving in order to benefit themselves). But see Manufacturers' Land \& Improvement Co. v. Cleary, $121 \mathrm{Ky} .403,89$ S.W. 248 (1905); Stott Realty Co. v. Orloff, 262 Mich. 375, 247 N.W. 698 (1933). The court stated in Riley v. Callahan Mining Co., 28 Idaho 525, 545, 155 Pac. 665, 672 (1916), that a corporation "is only another means of associating men together... for the achievement of a certain purpose, and when the purpose has manifestly failed, the compulsion to remain associated may as well be relaxed."

${ }^{20}$ E.g., Holden v. Lashley-Cox Land Co., 316 Mich. 478, 484, 25 N.W.2d 590, 592 (1947).

21 " $[W]$ here the corporation has been abandoned by its shareholders.... and is, therefore, powerless to protect its assets and to discharge its duty to the stockholders as their trustee, minority stockholders who are cestui que trust,... [may be entitled to dissolution]." Noble v. Gadsden Land \& Improvement Co., 133 Ala. 250, 254, 31 So. 856, 857 (1901) (land speculation corporation abandoned by majority after boom era passed with assets being depleted by taxes); Franklin Nat'1 Bank v. Kennerly Coal \&: Coke Co., 300 Pa. 479, 150 Atl. 902 (1930) (coal mining corporation abandoned for twenty-five years and merely continued to hold real estate). But see Central Land Co. v. Sullivan, 152 Ala. 360 , 44 So. 644 (1907).

22 Although one writer has suggested that dissension is not an independent ground for dissolution, even he admitted that it was frequently an important element. 41 Mich. L. REv. 714, 720 (1943). In a large number of cases, it would seem that courts have considered bickering, bitterness and enmity to be crucial factors. "There are many authorities which uphold the power of a court of chancery to dissolve a corporation because of dissensions of so serious a character as under the circumstances will inevitably defeat the purpose for which it was created." Flemming v. Heffner \& Flemming, 263 Mich. 561, 568, 248 N.W. 900, 902 (1933) (citing authoritics). In Green v. National Advertising \& Amusement Co., 137 Minn. 65, 162 N.W. 1056 (1917), the court focused upon "irreconcilable differences," "mutual hostility and enmity," "wrangling" and a situation that precluded an "amicable operation." Nelson v. United Elevators Co., 115 Kan. 567, 223 Pac. 814 (1924); Graham v. McAdoo, 135 Ky. 677, 123 S.W. 260 (1909); Hlawati v. Maeder-Hlawati Co., 289 Pa. 233, 137 Atl. 235 (1927); Nashville Packet Co. v. Neville, 144 Tenn. 698, 235 S.W. 64 (1921). But see Dorf v. Hill Bus Co., 140 N.J. Eq. 444, 54 A.2d 761 (Ct. Err. \&. App. 1947). Dissension and dcadlock are frequently related grounds for dissolution. Annot., 13 A.L.R.2d 1260 (1950).

Conceivably, in a situation characterized by extreme dissension, a mere refusal by the majority to dissolve might be deemed "oppressive" under the statutes, without a showing that the acts of the majority precipitated the dissension. See Kroger v. Jaburg, 231 App. Div. 641, 248 N.Y. Supp. 387 (1931).

${ }^{23}$ E.g., Kavanaugh v. Kavanaugh Knitting Co., 226 N.Y. 185, 123 N.E. 148 (1919) 
element in an action for dissolution under the "oppression" statutes. Controlling shareholders are not regarded as fiduciaries, in the classic sense, at common law or under the statutes; but general concepts of fiduciary law are frequently used in characterizing conduct by the majority that entitles the minority to relief. ${ }^{24}$ It would be stretching a point to say that the terms "oppression" and "breach of fiduciary duty" are identical, but there does seem to be substantial correlation between the two. Identical conduct may be deemed "oppressive" in one opinion and a "breach of fiduciary duty" in another. ${ }^{25}$ In other opinions the terms may be used almost interchangably. ${ }^{20}$ However, it would seem that a minor breach of a fiduciary duty, justifying some relief, might not be of such proportions as to be appropriately considered oppressive. Again it would be useless to suggest that one uncertain and indefinite term means the same as another.27

(fiduciary relationship); Noble v. Gadsden Land \& Improvement Co., 133 Ala. 250, 31 So. 856 (1901) (trust relationship). The leading case declarative of the fiduciary duty, although not involving dissolution, is Southern Pac. Co. v. Bogert, 250 U.S. 483 (1919), where it was stated that "the majority has the right to control; but when it does so, it occupies a fiduciary relation toward the minority, as much so as the corporation itself or its officers and directors." Id. at 487-88. . See generally Berle, Corporate Powers as Powers in Trust, 44 HARv. L. REv. 1049 (1931); Lattin, Equitable Limitations on Statutory or Charter Powers Given to Majority Stockholders, 30 Mich. L. Rev. 645 (1932); Lattin, The Minority Stockholder and Intra-Corporate Conflict, 17 Iowa L. REv. 313 (1932).

24 "[I]t is clear that the controlling stockholders are not fiduciaries in the strict sense; and indeed they could not be, for the classic fiduciary concept is incompatible with the principle that stockholder majorities shall effectively govern. However, the vocabulary and some of the content of the law of fiduciaries are employed to deal with instances of oppression." Hill, The Sale of Controlling Shares, 70 HaRv. L. REv. 986, 1015 (1957).

"The so-called fiduciary role of the insiders is invoked by the courts when selfishly motivated conduct exceeds certain bounds of fairness," as where a transaction "yields what are deemed unconscionable advantages to the insiders." Id. at 1014-15. Coinpare TiNGLE, op. cit. supra note 6 , at 41 , where the author half seriously suggests the dichotomy "enough oppression"-"not enough oppression" as the test for justifying dissolution.

25 Compare Barrett v. Smith, 185 Minn. 596, 242 N.W. 392 (1932), with Cullen v. Governor Clinton Co., 279 App. Div. 483, 110 N.Y.S.2d 614 (Sup. Ct. 1952) (directors voting excessive salaries to themselves as officers).

${ }^{20}$ For example, in Bowen v. Bowen-Romer Flour Mills Corp., 114 Kan. 95, 98, 217 Pac. 301, 303 (1923), the court talked at length about the majority's breach of trust, and then went on to say that "one group of belligerents has possession of the corporate property and control of its business affairs, and is taking advantage of the opportunity to oppress the other group." (Emphasis added.)

${ }_{27}$ Justice Frankfurter poimted out in SEC v. Chenery Corp., 318 U.S. 80, 85-86 (1943), that "to say that a man is a fiduciary only begins analysis; it gives direction to further inquiry. To whom is he a fiduciary? What obligations does he owe as a fiduciary?" 
"Fiduciary duty," for example, may mean that the corporation must be conducted "bona fide for the benefit of the company as a whole," ${ }^{28}$ or "breach of fiduciary duty" may involve "an overreaching of the minority at their expense either in material goods or interests which the law has deemed sufficiently important to recognize." 20 "Oppression," as used in a related but not identical context, ${ }^{30}$ has been found variously to suggest "burdensome, harsh and wrongful conduct," 31 "a lack of probity and fair dealing in the affairs of a company to the prejudice of some of its members," 32 or "a visible departure from the standards of fair dealing, and a violation of fair play on which every shareholder who entrusts his money to a company is entitled to rely." 33 Indeed the difficulty of finding a consistent definition is perhaps symptomatic of what seems to be the useful versatility of both the terms "fiduciary duty" and "oppression." While the courts and writers have been notably unsuccessful in articulating a viable definition of either of the terms, they have addressed themselves at length to the extent of the duties required by the fiduciary relationship. ${ }^{34}$ In determining whether oppression exists in an action under the statutes, a similar approach may be taken to delimit the duties owed to the minority, the violation of

\footnotetext{
${ }^{28}$ McPherson, Oppression of Minority Shareholders, Part 1, Common Law Relief, 36 AusTL. L.J. 404, 410 (1963).

${ }^{20}$ Lattin, The Minority Stockholder and Intra-Corporate Conflict, 17 Iowa L. REv. 313, 337 (1932).

30 There ate numerous cases construing the word "oppression" as it appears in $\$ 210$ of The [British] Companies Act of 1948, I1 \& 12 Geo. 6, c. 38. In essence, $\$ 210$ recognizes that in certain cases involuntary dissolution might be justified, but nonetheless unsatisfactory to complainants themselves. In such a situation and where it is shown that "the affairs of the company are being conducted in a manner oppressive to some part of the members," the court under $\S 210$ is authorized to make certain alternative orders for the relief of minority shareholders. Ibid. (Emphasis added.)

${ }^{81}$ Scottish Co-op. Wholesale Soc'y, Ltd. v. Meyer, [1958] 3 All E.R. 66, 71 (H.L.).

22 Id. at 86.

sa Elder v. Elder \& Watson, Ltd., [1952] Sess. Cas. 49, 55.

3* The concept of fiduciary obligations is an expanding one. See Perlman v. Feldmann, 219 F.2d 173 (2d Cir. 1955), cert. denied, 349 U.S. 952 (1955). Many types of conduct have already been declared violative of the fiduciary relationship. See, e.g., Jones v. Missouri-Edison Elec. Co., 144 Fed. 765 (8th Cir. 1906) (majority shareholders' sale of corporate property for personal gain at expense of minority); Guth v. Loft, Inc., 23 Del. Ch. 255, 5 A.2d 503 (Sup. Ct. 1939) (director purchasing property for purpose of resale to corporation); Cole v. National Cash Credit Ass'n, 18 Dcl. Ch. 47, 156 Atl. 183 (Ch. 1931) (majority shareholders' duty to require fair terms and equality of participation in merger); Oliver v. Oliver, $118 \mathrm{Ga} .362$, 45 S.E. 232 (1903) (failure of directors to disclose inside information in sale of shares); Elliott v. Baker, 194 Mass. 518, 80 N.E. 450 (1907) (directors manipulating control hy issuance of treasury stock). See LatTin, Corporations, 250-54, 271, 513-15 (1959).
} 
which might be deemed "oppressive." The concept that there are limitations on the power of controlling shareholders and directors is unmistakably implicit in both terms. What those limits are may depend upon what courts find to be the reasonable expectations of the minority in particular situations. ${ }^{35}$

\section{JUdicial INTERPRETATION OF THE STATUTES}

Only three recent Illinois cases have given extensive consideration to the term "oppressive" as it appears in the dissolution statutes, and in only one of these was the conduct complained of deemed "oppressive." 8 The judicial interpretations of the provision by the Illinois courts underscore a reliance upon the common law, but indicate some movement and development that should not be overlooked.

As at common law, the Illinois courts, even in the process of ordering dissolution under the oppression provision, are quick 20 add that a "drastic" remedy has been dispensed."s The courts still warn that

\footnotetext{
"Even though directors may be vested with reponsibility for mamging the corporate affairs, and certain percentages of shareholders empowered to make certain fundamental changes, "that should not mean, however, that the directors or the ma. jority sharcholders should be permitted to exercise their powers arbitrarily or without regard to the legitimate expectations of the minority sharcholders." ONEAs, op. cit. supra note $6, \$ 8.07$, at $107-08$.

Permissible conduct by the directors and shareholders would seem to be limited by statutes, judicial decisions, and the charter and by-laws of the corporation. In addition, shareholder agreements, dealing with employment, control, dividends, and the like, are becoming more common and are receiving wider acceptance by the courts. ONenl, supra, \$ 5.05, at 231. These agreements frequently serve to clarify and secure the expectations of the parties and may further proscribe conduct by the directors and majority shareholders. These agreements may be written or oral. As a seemingiy logical extension, courts might, even in the abience of specific agreement, imply certain restrictions on director and majority shareholder action, based on the expectations reasonably contemplated by the parties. See Standard IntI Corp. v. McDonald Printing Co., 159 N.E.2d 822, 824 (Ohio C.P. 1959), where the court recognized that the organizing shareholders of a close corporation had clearly contemplated limitations on the transfer of shares, and justified its decision on grounds that it would "perpetuate the company on the basis it had originally been set up."

se Gidwitz v. Lanzit Corrugated Box Co., 20 ill. 2d 208, 170 N.E.2d 131 (1960); Central Standard Life Ins. Co. v. Davis, 10 IIl. 2d 566, 141 N.E.2d 45 (1957); Polikoff v. Dole \& Clark Bldg. Corp., 37 III. App. 2d 29, 184 N.E.2d 792 (1962). In several other cases under Model Act type statutes, "oppression" was asserted along with other allegations and was summarily dealt with by the courts. Jesser $v$. Mayfair Hotel Inc., 316 S.W.2d 465 (Mo. 1958); Lush'us Brand Distribs., Inc. v. Fort Dearborn Lithograph Co., 330 III. App. 216, 70 N.E.2d 737 (I946); Long v. Wilson Stove \& Mfg. Co., 277 Ill. App. 57, 188 N.E. 411 (1933).

"7 Gidwitz v. Lanzit Corrugated Box Co., supra note 36.

sa Gidwitz v. Lanzit Corrugated Box Co., 20 III. 2d 208, 170 N.E.2d 131 (1960); Polikoff v. Dole \& Clark Bldg. Corp., 37 Ill. App. 2d 29, 184 N.E.2d 792 (I962).
} 
the granting of dissolution may give unjustified dominance to the will of the minority. ${ }^{39}$ They have reemphasized that they are unwilling to be a party to speculative maneuvering and will not readily interfere with the majority shareholders' timing in the disposition of corporate assets. ${ }^{40}$

Despite the traditional warnings, certain language in the Illinois decisions would seem to indicate that some of the time honored strictures may be eased under the "oppression" statutes. The showing of inevitable ruin is no longer a prerequisite to dissolution in Illinois. ${ }^{41}$ Mere continued corporate existence in the absence of prospective profitable operation might in an appropriate case constitute "oppression." 42 The overall emphasis seems to be on the "cumulative effects of . . . many acts and incidents, and their . . . continuing nature." 43 The recital of numerous acts of misconduct involving the sole asset of the corporation, coupled with disproportionate loss to the minority, may constitute a claim of "oppression." 44

\footnotetext{
${ }^{30}$ Polikoff v. Dole \& Clark Bldg. Corp., supra note 38.

${ }^{\circ}$ Central Standard Life Ins. Co. v. Davis, 10 Ill. 2d 566, 141 N.E.2d 45 (1957); Polikoff v. Dole \& Clark Bldg. Corp., 37 Ill. App. 2d 29, 184 N.E.2d 792 (1962). In Polikoff, the principal asset of the corporation was a building containing a hotel, a theatre and several stores in downtown Chicago. The theatre had remained idle for an expended period of time. Continued payments toward retiring a loan that had been made to the corporation by the wife of defendant Grundman, who was president and majority shareholder, were uncertain. The loan was secured by a mortgage on the property, and plaintiff feared the loss of the building to Mrs. Grundman. The complaint alleged that various acts of Mr. Grundman in his "doubly dominant" position were "oppressive." But the appellate court affirmed the lower court's dismissal. In Davis, the majority shareholder of a hotel corporation resisted dissolution. Plaintiff, holder of 4098 out of 7250 shares of preferred stock, alleged that the corporation had accumulated dividends of just over $\$ 1,000,000$, that the operating history of the company indicated that it would never make a profit sufficient to pay accrued dividends, and that refusal to liquidate the corporate assets worth $\$ 1,753,000$ (by plaintiff's appraisal) was oppressive. The court refused to dissolve the corporation.

It is submitted that the result in Davis is clearly warranted. Plaintiffs there held only ten out of 8000 shares of common stock, and there was no evidence of bad faith on the part of defendants. It would seem that the result in Polikoff is less tenable. See note 44 infra.

"1 "The word 'oppressive" does not carry an essential inference of imminent dis. aster; it can, we think, contemplate a continuing course of conduct." Central Standard Life Ins. Co. v. Davis, I0 Ill. 2d 566, 573, I41 N.E.2d 45, 50 (1957) (dictum). But see Jesser v. Mayfair Hotel, Inc., 316 S.W.2d 465, 473 (Mo. I958).

$\$$ Central Standard Life Ins. Co. v. Davis, supra note 41; Polikoff v. Dole \& Clark Bldg. Corp., 37 Ill. App. 2d 29, 184 N.E.2d 792 (1962) (dictum).

${ }^{4}$ Gidwitz v. Lanzit Corrugated Box Co., 20 Ill. 2d 208, 221, 170 N.E.2d 131, 138 (1960).

" Polikoff v. Dole \& Clark Bldg. Corp., 37 Ill. App. 2d 29, 39, 184 N.E.2d 792, 796 (1962) (dissenting opinion). The dissent, it is submitted, is more nearly in line with both the language of the common law decisions and the tenor of Gidwilz
} 
The showing of such facts may shift the burden to defendants to establish the fairness of their position. ${ }^{45}$ Quite apart from the discussion as to what need be demonstrated to support a petition for dissolution under the statutes, the Illinois courts have made clear that "oppression" is in and of itself a basis for dissolution. "Oppression" is an independent ground for relief, not requiring a showing of fraud, illegality, mismanagement, wasting of assets, nor deadlock, although those factors might be and frequently are present. ${ }^{48}$ The Illinois courts have not provided an inclusive definition of "oppression." But even when used in its ordinary sense the term may have sufficient substance to be useful.47 The very absence of definite and restrictive boundaries tends to enhance the flexibility of the term and may constitute one of the most beneficial aspects of its inclusion in the statutes. The "oppression" provision has already been used to justify dissolution where another provision of the same statute, and precedent construing it, was too narrow to provide relief. ${ }^{48}$ The "oppression" provision would seem to be a ready

and Davis. The alleged misconduct (excessive salaries and refusal either to operate or to sell the assets) and failure of the purposes for which the corporation had been reorganized (viz. retirement of the Class $A$ stock), in a context in which the majority alone stood to gain by foreclosure, seems at least to suggest bad faith and to state a cause of action. Even if the result is supportable, it would seem that the language of the majority opinion is unduly restrictive.

"L See Polikoff v. Dole \& Clark Bldg. Corp., supra note 44.

¿0 "[T] he word 'oppressive' does not necessarily savor of fraud, and... the absence of 'mismanagement, or misapplication of assets' does not prevent a finding that the conduct... has been oppressive." Central Standard Life Ins. Co. v. Davis, 10 Ill. 2d $566,573,141$ N.E.2d 45, 50 (1959). "It is not necessary that fraud, illegality or even loss be shown to exhibit oppression." Gidwitz v. Lanzit Corrugated Box Co., 20 Ill. 2d 208, 214-15, 170 N.E.2d 131, 138 (1960).

17 The court in Re H.R. Harmer, Ltd. [1958] 3 All E.R. 689 (C.A.), for example, did not labor with definitions in a situation arising under $\$ 210$ of the British Companies Act of 1948, 11 \& 12 Geo. 6, c. 38 (see note 30 supra). "[O]ppression must be given its ordinary sense." Id. at 698 . The court said simply and graphically, "he [fathermajority shareholder in family corporation] rode roughshod over his sons and everybody else... in some instances in disregard of the best interest of the company itself." Id. at 706 .

${ }^{48}$ Gidwitz v. Lanzit Corrugated Box Co., 20 Ill. 2d 208, 170 N.E.2d 131 (1960). In Gidwitz defendant owned $50 \%$ of the stock in a closely held, deadlocked corporation, which he had managed and controlled for ten years as president. During that time, he had acted in an "arbitrary and highhanded manner" in numerous transactions, particularly in relation to control of his employment and salaries. Plaintiff, who likewise held $50 \%$ of the shares, was completely excluded from management. The deadlock provision of the involuntary dissolution statute, and strong precedent, required a showing of irreparable injury to the corporation. Inasmuch as this could not be shown, the court relied upon the "oppressive" provision. See 74 HARv. L. REv. 146I (1961). 
tool for dealing with situations not falling within the more definitive subsections of the acts. It may be expected to afford relief in a variety of situations that range from exclusion from management in a family corporation $^{4 \theta}$ to deliberate destruction of a subsidiary by the parent corporation. ${ }^{50}$

\section{Factors Contributing to the Appropriateness \\ of Dissolution as the Remedy for Oppression}

Even after characterizing the conduct of directors or controlling interests as "oppressive" or violative of some "fiduciary duty," courts often select some remedy other than dissolution. ${ }^{51}$ Whether the fact of "oppression" justifies dissolution in a particular case would seem to depend on a weighing of additional factors and counterfactors which often remain inarticulated.

Both at common law and under statute, the corporations most frequently dissolved have been those closely held. The peculiar incidents of the close corporation make such a result predictable and easily explainable..$^{52}$ Close corporations are often little more than incorporated partnerships. Stock ownership may be fairly evenly distributed among the members of one or two families. Formalities are usually relaxed, and the affairs of the corporation are normally directed on the basis of consensus and cooperation. In this context, misconduct, dissension, deadlock and bad faith assume special sig-

\footnotetext{
40 Gidwitz v. Lanzit Corrugated Box Co., supra note 48.

${ }^{50}$ See Scottish Co-op. Wholesale Soc'y, Ltd. v. Meyer, [1958] 3 All E.R. 66, 71 (H.L.) (Scot.).

${ }^{81} \mathrm{Cf}$. text accompanying note 7 supra. The Model Act type statutes are generally permissive and dissolution remains in the discretion of the court even after oppressive conduct has been shown. The nature of the statutes in this respect was emphasized in a recent decision under the deadlock provision of a Model Act type statute. Jackson v. Nicolai-Neppach Co., 219 Ore. 560, 348 P.2d 9 (1959). The statutes are frequently directed merely at a claimed jurisdictional deficiency. See text accompanying note 8 supra. The Model Business Corporation Act $\$ 90$, for example, is captioncd "Jurisdiction of Court to Liquidate Assets and Business of Corporation." The committee revising the Model Act in 1950 explained that "such remedies [as appointment of receiver and dissolution] may be very useful, but the jurisdiction and authority of the state courts might be in doubt if there is no express statutory provision." ABA-ALI MODEL Bus. Corp. ACT at ix (rev. 1950).

52 The special characteristics and needs of the close corporation, as distinguished from those of a public issue corporation, have received increasing recognition. Sec generally O'Nen工, Close Corporations: LAw and Practice (1958); Hornstein, Judicial Tolerance of the Incorporated Partnership, 18 LAw \& CoNTEMP. ProB. 435 (1953); Latty, The Close Corporation and the New North Carolina Business Corporation Act, 34 N.C.L. REv. 432 (1956); Oppenheim, The Close Corporation in California-Necessity of Separate Treatment, 12 HAstings L.J. 227 (1961); Symposium-The Close Corporation, 52 Nw. U.L. REv. 345 (1957).
} 
nificance and may more readily constitute "oppression" of such proportions as to justify dissolution. The restricted market normally available for the shares of a close corporation makes inappropriate the frequent judicial pronouncements that a shareholder's remedy is to sell his shares. A forced marriage of dissident or distrusting parties in a close corporation may be particularly wasteful, unprofitable and burdensome. 'Thus where misconduct by. the directors or controlling interests is of such a degree as to generate a "justifiable lack of confidence," 53 dissolution may be the only appropriate remedy under existing statutes.

However, in spite of these special features, the existence of the close corporation is, in the view of many, too often regarded as inviolable. ${ }^{54}$ In light of equity's successful handling of the dissolution of partnerships, it is submitted that the courts could utilize the "oppression" concept to make the remedy of dissolution more readily available to minority shareholders of close corporations. ${ }^{55}$

In determining whether dissolution is the appropriate remedy, courts frequently give special attention to the prospects for the future. ${ }^{58}$ While derivative actions for waste and other relief require an examination of past conduct, actions for dissolution demand additionally an appraisal of the future. The courts may look for a "pattern of conduct by the dominant shareholders and a disposition on their part to continue the pattern"57 that is violative of the rights and interests of the minority. Where the future holds "no hope of abatement," or where the majority is "incorrigible,"58 dis-

\footnotetext{
sí See note 18 supra.

\&4 "This sacred cow has all too often been an effective road block in cases where the over-all best interests of the owners of the enterprise call for its dissolution or liquidation." Israels, The Sacred Cow of Corporate Existence: Problems of Deadlock and Dissolution, 19 U. CHI. L. REv. 778 (1952). "[P]articipants frequently suffer economically when their business is terminated. Yet in a close corporation, far more often than is commonly supposed, dissolution is the only answer." O'NEAL, op. cit. supra note 50, at $\$$ 9.03. Hornstein, A Remedy for Corporate Abuse-Judicial Power to Wind Up a Corporation at the Suit of a Minority Stockholder, 40 CoLuM. L. REv. 220 (1940).

${ }^{5}$ The functional similarities between partnerships and close corporations have received significant attention, chiefiy from the writers, but occasionally from the courts. See, e.g., In re Yenidje Tobacco Co., [1916] $2 \mathrm{Ch}$. 426. One writer sets forth the liberal dissolution provisions of the Uniform Partnership Act in suggesting guidelines for increased use of dissolution in the case of close corporations. Israels, supra note 54, at 789. See I O'NEAL, op. cit. supra note 52, at \$ 5.02; Oppenheim, supra note 52, at 254 .

¿6 Gidwitz v. Lanzit Corrugated Box Co., 20 IIl. 2d 208, 220, 170 N.E.2d 131, 138 (1960).

${ }^{87}$ Bellevue Gardens, Inc. v. Hill, 297 F.2d 185, 187 (D.C. Cir. 1961).

${ }^{88}$ One writer has suggested that majority incorrigibility appeared consistently as a factor in the common law dissolution decrees. TincLe, op. cit. supra note 6 , at 43 .
} 
solution may be in order. Such a condition may be precipitated by a single act or a continuing course of conduct. It is submitted that this approach, which "is not so much to rake up the past as to redeem the future," ${ }^{159}$ is sound and helpful, and should be utilized in determining whether "oppression" is of a nature to warrant dissolution.

In light of the history of the dissolution remedy and the deference paid to the mythical corporate creature, the foregoing considerations and arguments for dissolution could hardly be expected to go unopposed. The New York courts, in considering shareholder petitions for dissolution, have been particularly conscious of what they term "injury to the public." 00 This phrase would seem to serve as a convenient rubric for such factors as the effect of dissolution upon employees, customers, contractors and creditors. However, this does not mean that dissolution will be limited to small corporations with few customers or employees. ${ }^{61}$

The value to be realized from the forced sale of the corporate assets may also cause courts to balk at ordering dissolution even though oppressive conduct has been shown. ${ }^{62}$ The nature of the assets, whether they be specialized machinery or good will, may make predictable a disproportionately low receipt upon dissolution, and a court might be justified in appointing a temporary receiver to monitor the affairs of the corporation or to employ some other remedy. However, the extent of the majority misconduct, the probability that the majority will be buying the assets at the forced sale, the rate at which the value of the assets are declining, and the proportion of the loss from forced sale that will be borne by the wrongdoing majority may nonetheless justify the loss of value occasioned by liquidation.

\section{ConCLUSION}

Circumstances which may give rise to "oppression" are "so infinitely various that it is impossible to define them with precision." 63 It

${ }^{\circ} \mathrm{Re}$ H.R. Harmer, Ltd., [1958] 3 All. E.R. 689, 696 (C.A.).

${ }^{\circ}$ See, e.g., In re Radom v. Neidorf, Inc., 307 N.Y. 1, 119 N.E.2d 563 (1954); In re Seamerlin Operating Co., 307 N.Y. 407, 121 N.E.2d 392 (1954). The New York statute providing for dissolution of a deadlocked corporation specifically establishes as a standard that dissolution is to be "beneficial to the stockholder or members and not injurious to the public." N.Y. GEN. CoRP. LAw $\$ 117$.

1 See, e.g., Henry v. Ide, 208 Ala. 33, 93 So. 860 (1922); Hall v. City Park Brewing Co., 294 Pa. 127, 143 Atl. 582 (1928).

*see Patton v. Nicholas, 154 Tex. 385, 398, 279 S.W.2d 848, 854 (1955).

${ }^{\circ} \mathrm{Re}$ H.R. Harmer, Ltd., [1958] 8 All E.R. 689, 698-99. 
might be added, moreover, that any attempt to define "oppressive" would tend to reduce the flexibility of the provision. "Oppressive" is no less vague or abstruse than "fiduciary duty" or "trust relationship," phrases which have been productively employed. The term has sufficient definition, substance and legal currency to warrant additional usage in Model Act states.

If, as numerous courts have indicated, the statutory remedy is to be considered exclusive, ${ }^{64}$ it should at least be construed to include the pre-existing common law bases for granting dissolution. Insofar as this may be done without unduly torturing the familiar meaning of the word, "oppressive" should be employed in the Model Act states to provide equivalent coverage. While some of the provisions of the Model Act have built-in limitations, such as a requisite showing of irreparable damage in the case of deadlock, "oppression" has not been so restricted. The existing decisions under the statute, except for unnecessarily broad reservations in one opinion, ${ }^{65}$ reflect a recognition of the latitude of the provision and represent some willingness to extend its use beyond the common law situations.

Although statutory phrases such as "just and equitable"68 and "in a manner unfairly pre-judicial" 67 may be more malleable, "oppressive" would seem pliable enough to extend ample protection to the rights of the minority. The logical point of departure for determining what those rights are would seem to be the shareholder's reasonable expectations, which will differ depending upon the nature of the corporation and other circumstances. These may extend from the expectation that the corporation will be run honestly and ratably for the benefit of all the shareholders to the expectation that the shareholder will be allowed to participate in management. If it appears that these anticipated prerogatives are to be continually thwarted in the future, the conduct may appropriately be considered oppressive within the meaning of the statute.

\footnotetext{
ot See note 10 supra.

or Polikoff v. Dole \& Clark Bldg. Corp., 37 IIl. App. 2d 29, 184 N.E.2d 792 (I962). See note 44 supra.

${ }^{\circ 0}$ See, e.g., The Companies Act, 1948, 11 \& 12 Geo. 6, c. 38, § 222.

${ }^{\circ 7}$ See Heerey, Shareholder's Petition in Cases of Oppression, 36 Austr. L.J. 187, 192 n.62 (1963).
} 